\title{
Leptin Resistance and the Neuro-Adipose Connection
}

\author{
Andreia Barateiro ${ }^{1,2}$, Ines Mahú ${ }^{\text {and }}$ Ana I. Domingos ${ }^{1 *}$ \\ ${ }^{1}$ Obesity Laboratory, Instituto Gulbenkian de Ciência, Oeiras, Portugal, ${ }^{2}$ Faculty of Pharmacy, Research Institute for \\ Medicines (iMed.ULisboa), Universidade de Lisboa, Lisbon, Portugal
}

Keywords: leptin resistance, metabolic syndrome, MONA LISA hypothesis, obesity, sympathetic neurons

Obesity is a public health concern affecting both genders at all ages around the world (1). The worldwide prevalence of obesity is rapidly increasing and has nearly doubled between 1980 and 2016 (2). Consequently, it places a large financial burden on the economy due to the increased morbidity and mortality, as well as the reduced quality of life and development of chronic diseases (3). Obesity is typically characterized by excessive amounts of the hormone leptin, a cytokine-like molecule produced in white adipose tissue (WAT) that is secreted into the systemic circulation (4). The circulating levels of leptin are proportional to the amount of fat and function as the afferent signal in a negative feedback loop that seeks to maintain body fat in a very narrow range of variation (5). Leptin has a central role in body weight homeostasis due to its inhibition of food intake inhibition and stimulation of energy expenditure. The effect of leptin on body weight is attributed to its action in a specific brain region, the hypothalamus. Hence, leptin is released by adipocytes in proportion to the size of fat depots, enters the circulation, and reaches the central nervous system by crossing the blood-brain barrier (BBB) through receptor-mediated endocytosis (6) in which it acts mainly through the arcuate nucleus of the hypothalamus to mediate most of its actions (7). Specifically, leptin modulates the activity of two types of neurons to inhibit appetite, through production of anorexigenic peptides by the pro-opiomelanocortin (POMC) neurons (8) and suppression of the orexigenic agouti-related protein (AgRP) neurons (9). Besides acting on the hypothalamus to suppress appetite, leptin also induces lipolysis in WAT and thermogenesis in brown adipose tissue (BAT) and browning of WAT, via the activation of the sympathetic nervous system (SNS) (10). However, in most obese subjects, despite its high serum levels, leptin fails to perform its physiological functions and consequently fails to reduce weight $(11,12)$. This effect has been coined as leptin resistance.

The concept of leptin resistance is used to define states where hyperleptinemia is combined to lack of response to the hormone, with consequent maintenance of body weight excess and increased food consumption (13). Nevertheless, it has been described that the effect of leptin treatment on the control of body weight through the regulation of both food intake and energy expenditure is differently exerted in lean and obese humans, suggesting different sensitivity to the hormone (14). Although the mechanisms behind the development of leptin resistance are still unclear, several models have been proposed. As the hypothalamus mediates the anti-obesity actions of leptin, one of the models proposed a decrease in leptin transport across the BBB (15). In addition, a more recent study has shown that $\mathrm{BBB}$ impairment can also be attributed to higher plasmatic levels of cytokines and fatty acids in obese subjects (16). Another proposed mechanism is the disruption of leptin signal transduction as several proteins are able to inhibit the signaling from cytokine receptors $(17,18)$. In this context, suppressor of cytokine signaling 3 (SOCS3) seems to be a key protein in central leptin resistance because its loss of function in the hypothalamus confers protection to high-fat diet (HFD)-induced obesity (19). Other studies have also demonstrated that HFD induces SOCS3 expression by leptin in POMC and AgRP neurons (20,21). More recently, increased endoplasmic reticulum stress was also suggested as a mediator of the obesity-associated central leptin resistance (22). Interestingly, hypothalamic inflammation is also emerging as a key mechanism 
for leptin resistance development as it can be responsible for structural changes leading to inefficient circuits in food intake control (22-24). As an early response to HFD, reactive glial cells are able to proliferate and acquire a proinflammatory state even within few days before the detection of significant alterations in body weight (25). This early inflammatory response is neuroprotective. However, the following chronic inflammatory state is responsible for synaptic alterations in the hypothalamus that are connected to the loss of leptin responsiveness (26). Moreover, several studies have demonstrated that inflammatory mediators, such as tumor necrosis factor $\alpha$ (TNF- $\alpha$ ), interleukin $1 \beta$ (IL-1 $\beta$ ), and $C$ reactive protein, are elevated in obesity (27-29) and are involved in the increase of circulating leptin concentrations in rodents and humans, suggesting that these factors may be related to hyperleptinemia and leptin resistance onset $(30,31)$. Interestingly, the ablation of IL- $1 \beta$ receptor and TNF- $\alpha$ receptor 1 in mice protects from obesity induced by $\operatorname{HFD}(32,33)$. On the other hand, other studies have already demonstrated that leptin is able to induce the secretion of proinflammatory cytokines (34).

But, when it comes to defining leptin resistance, it seems that our understanding of the involvement of hyperleptinemia in the development of impaired satiety is far more understood than that which is responsible for the loss of the lipolytic action of leptin. So, besides not so studied, a parallel peripheral leptin resistance can occur (35). In fact, elevation of SNS tone in WAT and BAT is essential for the dissipation of energy via activation of beta-adrenergic receptors post-synapticaly in target organs (36). Hence, the induction of lipolysis could be a therapeutic target in the context of obesity management, but for that we need to understand both how leptin controls the SNS output to WAT (37) and BAT (38) and how the decrease in energy expenditure observed upon leptin resistance develops, consequently driving the progression of obesity into metabolic syndrome.

The definition of metabolic syndrome, for which leptin resistance is one of the major risk factors, highlights the connection between elevation of metabolic markers (abdominal obesity, high triglyceride, low high-density lipoprotein cholesterol blood concentrations, and hyperglycemia) and elevation of risk for developing cardiovascular diseases (39). Moreover, obesity has been associated with a chronic increase of sympathetic tone, which can explain the development of obesity-associated hypertension and other cardiovascular morbidities. These associations were based on observation of increased urinary noradrenaline, efferent muscle sympathetic nerve activity (MSNA), and noradrenaline spillover (global and regional) to the plasma in obese subjects (40). In the context of positive energy balance, the increase in SNS activity in obese individuals would serve the purpose of counteracting adiposity, by increasing energy expenditure and preventing weight gain (40). However, such increase of SNS tone seems to be differentially distributed across organs, such as heart, blood vessel muscle, or various fat depots. Indeed, abdominal visceral fat volume positively correlates with MSNA, while subcutaneous adipose mass seems not to be correlated with MSNA (41). The heart, kidney and muscle seem to be the major targets of increased sympathetic tone in obesity, linked to the development of hypertension, while limited lipolytic responsiveness to SNS-mediated stimuli in WAT might explain the impaired ability to use fat stores and progression of the disease (42). Hence, there is a need for a more complex understanding of how leptin drives SNS activity than what we currently have. The activity of SNS has been described to be preserved/elevated in other tissues and lost specifically in the adipose tissue (both WAT and BAT). As such, leptin resistance could entail catecholamine resistance in the adipose tissue (43). Consistent with this idea, recent studies have shown that sympathetic neuro-adipose junctions drive local lipolysis in the adipose tissue (37). Local gain-of-function of sympathetic neuronal activity in the inguinal fat pad drives local lipolysis and local reduction of fat mass (37). Conversely, local loss-offunction of sympathetic neurons in the fat pad abrogates leptin's lipolytic action in a local manner (37).

Taking into account all the aspects referred above, leptin resistance may also involve decreased sympathetic local activity, within the adipose organ. In this regard, and before the leptin era, George Bray and others proposed the "MONA LISA" hypothesis (Most Obesities kNown Are Low In Sympathetic Activity). This hypothesis was built up from studies of SNS activity and norepinephrine decay in obese patients and rats (44-46). However, under the light of the well-known obesity induced hypertension, which is associated with increased sympathetic drive to the vasculature and kidney, the MONA LISA hypothesis was later regarded as a paradoxical model (47). The conciliation of having low and high SNS activity in the same model was difficult to attain at a time when the molecular genetics of obesity was giving its first steps. The view that a multitude of cells has to respond in the same manner to the same stimulus, such as obesity, assumes that all SNS neurons are identical. This type of tabula rasa models precede the era of molecular genetics, which paved the way for molecular and functional diversity of seemingly alike cells. Indeed, the era of molecular genetics has enabled the mechanistic dissection of brain circuits, as well as, the immune system in spectacular ways. However, the molecular and circuit organization of the SNS, which innervates all known organs, is essentially unexplored. A molecular neuroanatomical map of the SNS may in turn revive the MONA LISA hypothesis. Once we understand the diversity of the SNS from a molecular and circuit standpoint, we then may be closer to resolving the mistery of leptin resistance.

\section{AUTHOR CONTRIBUTIONS}

All authors listed have made substantial, direct, and intellectual contribution to the work and approved it for publication.

\section{FUNDING}

$\mathrm{AB}$ and IM have fellowships from the Fundação para Ciência e Tecnologia (FCT) (SFRH/BPD/96794/2013 and PD/ $\mathrm{BD} / 52437 / 2013$, respectively). $\mathrm{AD}$ was supported by funds from the FCT (PTDC-BIM-MET-3750-2014), the European Molecular Biology Organization (EMBO) (IG3077), the Prémios Maratona Saúde 2015 (Diabetes), and the Human Frontiers Science Program (HFSP) (RGY0070/2016). 


\section{REFERENCES}

1. Ng M, Fleming T, Robinson M, Thomson B, Graetz N, Margono C, et al. Global, regional, and national prevalence of overweight and obesity in children and adults during 1980-2013: a systematic analysis for the Global Burden of Disease Study 2013. Lancet (2014) 384:766-81. doi:10.1016/ S0140-6736(14)60460-8

2. World Health Organization. Obesity and Overweight Fact Sheet [Internet]. World Health Organization (2016). Available from: http://www.who.int/ mediacentre/factsheets/fs311/en/

3. Mehta T, Fontaine KR, Keith SW, Bangalore SS, de los Campos G, Bartolucci A, et al. Obesity and mortality: are the risks declining? Evidence from multiple prospective studies in the United States. Obes Rev (2014) 15:619-29. doi:10.1111/obr.12191

4. Zhang Y, Proenca R, Maffei M, Barone M, Leopold L, Friedman JM. Positional cloning of the mouse obese gene and its human homologue. Nature (1994) 372:425-32. doi:10.1038/372425a0

5. Friedman JM, Halaas JL. Leptin and the regulation of body weight in mammals. Nature (1998) 395:763-70. doi:10.1038/27376

6. Golden PL, Maccagnan TJ, Pardridge WM. Human blood-brain barrier leptin receptor. Binding and endocytosis in isolated human brain microvessels. J Clin Invest (1997) 99:14-8. doi:10.1172/JCI119125

7. Woods AJ, Stock MJ. Leptin activation in hypothalamus. Nature (1996) 381:745. doi:10.1038/381745a0

8. Seeley RJ, Yagaloff KA, Fisher SL, Burn P, Thiele TE, van Dijk G, et al. Melanocortin receptors in leptin effects. Nature (1997) 390:349. doi: $10.1038 / 37019$

9. Mizuno TM, Mobbs CV. Hypothalamic agouti-related protein messenger ribonucleic acid is inhibited by leptin and stimulated by fasting. Endocrinology (1999) 140:814-7. doi:10.1210/endo.140.2.6491

10. Seoane-Collazo P, Ferno J, Gonzalez F, Dieguez C, Leis R, Nogueiras R, et al. Hypothalamic-autonomic control of energy homeostasis. Endocrine (2015) 50:276-91. doi:10.1007/s12020-015-0658-y

11. Martin SS, Qasim A, Reilly MP. Leptin resistance: a possible interface of inflammation and metabolism in obesity-related cardiovascular disease. J Am Coll Cardiol (2008) 52:1201-10. doi:10.1016/j.jacc.2008.05.060

12. Myers MG Jr, Leibel RL, Seeley RJ, Schwartz MW. Obesity and leptin resistance: distinguishing cause from effect. Trends Endocrinol Metab (2010) 21:643-51. doi:10.1016/j.tem.2010.08.002

13. Halaas JL, Gajiwala KS, Maffei M, Cohen SL, Chait BT, Rabinowitz D, et al. Weight-reducing effects of the plasma protein encoded by the obese gene. Science (1995) 269:543-6. doi:10.1126/science.7624777

14. Dodt C, Lonnroth P, Wellhoner JP, Fehm HL, Elam M. Sympathetic control of white adipose tissue in lean and obese humans. Acta Physiol Scand (2003) 177:351-7. doi:10.1046/j.1365-201X.2003.01077.x

15. Van Heek M, Compton DS, France CF, Tedesco RP, Fawzi AB, Graziano $\mathrm{MP}$, et al. Diet-induced obese mice develop peripheral, but not central, resistance to leptin. J Clin Invest (1997) 99:385-90. doi:10.1172/ JCI119171

16. Oh IS, Shimizu H, Sato T, Uehara Y, Okada S, Mori M. Molecular mechanisms associated with leptin resistance: n-3 polyunsaturated fatty acids induce alterations in the tight junction of the brain. Cell Metab (2005) 1:331-41. doi:10.1016/j.cmet.2005.04.004

17. Bjornholm M, Munzberg H, Leshan RL, Villanueva EC, Bates SH, Louis GW, et al. Mice lacking inhibitory leptin receptor signals are lean with normal endocrine function. J Clin Invest (2007) 117:1354-60. doi:10.1172/ JCI30688

18. Zabolotny JM, Bence-Hanulec KK, Stricker-Krongrad A, Haj F, Wang Y, Minokoshi Y, et al. PTP1B regulates leptin signal transduction in vivo. Dev Cell (2002) 2:489-95. doi:10.1016/S1534-5807(02)00148-X

19. Liu ZJ, Bian J, Zhao YL, Zhang X, Zou N, Li D. Lentiviral vector mediated knockdown of SOCS3 in the hypothalamus protects against the development of diet-induced obesity in rats. Diabetes Obes Metab (2011) 13:885-92. doi:10.1111/j.1463-1326.2011.01419.x

20. Gamber KM, Huo L, Ha S, Hairston JE, Greeley S, Bjorbaek C. Over expression of leptin receptors in hypothalamic POMC neurons increases susceptibility to diet-induced obesity. PLoS One (2012) 7:e30485. doi:10.1371/ journal.pone.0030485
21. Olofsson LE, Unger EK, Cheung CC, Xu AW. Modulation of AgRP neuronal function by SOCS3 as an initiating event in diet-induced hypothalamic leptin resistance. Proc Natl Acad Sci U S A (2013) 110:E697-706. doi:10.1073/ pnas. 1218284110

22. Zhang X, Zhang G, Zhang H, Karin M, Bai H, Cai D. Hypothalamic IKKbeta/ NF-kappaB and ER stress link overnutrition to energy imbalance and obesity. Cell (2008) 135:61-73. doi:10.1016/j.cell.2008.07.043

23. De Souza CT, Araujo EP, Bordin S, Ashimine R, Zollner RL, Boschero AC, et al. Consumption of a fat-rich diet activates a proinflammatory response and induces insulin resistance in the hypothalamus. Endocrinology (2005) 146:4192-9. doi:10.1210/en.2004-1520

24. Thaler JP, Guyenet SJ, Dorfman MD, Wisse BE, Schwartz MW. Hypothalamic inflammation: marker or mechanism of obesity pathogenesis? Diabetes (2013) 62:2629-34. doi:10.2337/db12-1605

25. Garcia-Caceres C, Yi CX, Tschop MH. Hypothalamic astrocytes in obesity. Endocrinol Metab Clin North Am (2013) 42:57-66. doi:10.1016/j. ecl.2012.11.003

26. Horvath TL, Sarman B, Garcia-Caceres C, Enriori PJ, Sotonyi P, Shanabrough $\mathrm{M}$, et al. Synaptic input organization of the melanocortin system predicts diet-induced hypothalamic reactive gliosis and obesity. Proc Natl Acad Sci U S A (2010) 107:14875-80. doi:10.1073/pnas.1004282107

27. Hotamisligil GS, Arner P, Caro JF, Atkinson RL, Spiegelman BM. Increased adipose tissue expression of tumor necrosis factor-alpha in human obesity and insulin resistance. J Clin Invest (1995) 95:2409-15. doi:10.1172/ JCI117936

28. Corica F, Allegra A, Corsonello A, Buemi M, Calapai G, Ruello A, et al. Relationship between plasma leptin levels and the tumor necrosis factor-alpha system in obese subjects. Int J Obes Relat Metab Disord (1999) 23:355-60. doi:10.1038/sj.ijo.0800826

29. Devaraj S, Singh U, Jialal I. Human C-reactive protein and the metabolic syndrome. Curr Opin Lipidol (2009) 20:182-9. doi:10.1097/ MOL.0b013e32832ac03e

30. Kirchgessner TG, Uysal KT, Wiesbrock SM, Marino MW, Hotamisligil GS. Tumor necrosis factor-alpha contributes to obesity-related hyperleptinemia by regulating leptin release from adipocytes. J Clin Invest (1997) 100:2777-82. doi:10.1172/JCI119824

31. Zumbach MS, Boehme MW, Wahl P, Stremmel W, Ziegler R, Nawroth PP. Tumor necrosis factor increases serum leptin levels in humans. J Clin Endocrinol Metab (1997) 82:4080-2. doi:10.1210/jcem.82.12.4408

32. Somm E, Henrichot E, Pernin A, Juge-Aubry CE, Muzzin P, Dayer JM, et al. Decreased fat mass in interleukin-1 receptor antagonist-deficient mice: impact on adipogenesis, food intake, and energy expenditure. Diabetes (2005) 54:3503-9. doi:10.2337/diabetes.54.12.3503

33. Romanatto T, Roman EA, Arruda AP, Denis RG, Solon C, Milanski M, et al. Deletion of tumor necrosis factor-alpha receptor 1 (TNFR1) protects against diet-induced obesity by means of increased thermogenesis. J Biol Chem (2009) 284:36213-22. doi:10.1074/jbc.M109.030874

34. Loffreda S, Yang SQ, Lin HZ, Karp CL, Brengman ML, Wang DJ, et al. Leptin regulates proinflammatory immune responses. FASEB J (1998) 12:57-65.

35. Sainz N, Barrenetxe J, Moreno-Aliaga MJ, Martinez JA. Leptin resistance and diet-induced obesity: central and peripheral actions of leptin. Metabolism (2015) 64:35-46. doi:10.1016/j.metabol.2014.10.015

36. Thorp AA, Schlaich MP. Relevance of sympathetic nervous system activation in obesity and metabolic syndrome. J Diabetes Res (2015) 2015:341583. doi: $10.1155 / 2015 / 341583$

37. Zeng W, Pirzgalska RM, Pereira MM, Kubasova N, Barateiro A, Seixas E, et al. Sympathetic neuro-adipose connections mediate leptin-driven lipolysis. Cell (2015) 163:84-94. doi:10.1016/j.cell.2015.08.055

38. Enriori PJ, Sinnayah P, Simonds SE, Garcia Rudaz C, Cowley MA. Leptin action in the dorsomedial hypothalamus increases sympathetic tone to brown adipose tissue in spite of systemic leptin resistance. J Neurosci (2011) 31:12189-97. doi:10.1523/JNEUROSCI.2336-11.2011

39. Schlaich M, Straznicky N, Lambert E, Lambert G. Metabolic syndrome: a sympathetic disease? Lancet Diabetes Endocrinol (2015) 3:148-57. doi:10.1016/S2213-8587(14)70033-6

40. Bartness TJ, Liu Y, Shrestha YB, Ryu V. Neural innervation of white adipose tissue and the control of lipolysis. Front Neuroendocrinol (2014) 35:473-93. doi:10.1016/j.yfrne.2014.04.001 
41. Alvarez GE, Ballard TP, Beske SD, Davy KP. Subcutaneous obesity is not associated with sympathetic neural activation. Am J Physiol Heart Circ Physiol (2004) 287:H414-8. doi:10.1152/ajpheart.01046.2003

42. Davy KP, Orr JS. Sympathetic nervous system behavior in human obesity. Neurosci Biobehav Rev (2009) 33:116-24. doi:10.1016/j.neubiorev.2008.05.024

43. Mowers J, Uhm M, Reilly SM, Simon J, Leto D, Chiang SH, et al. Inflammation produces catecholamine resistance in obesity via activation of PDE3B by the protein kinases IKKepsilon and TBK1IKKepsilon and TBK1. Elife (2013) 2:e01119. doi:10.7554/eLife.01119

44. Young JB, Landsberg L. Stimulation of the sympathetic nervous system during sucrose feeding. Nature (1977) 269:615-7. doi:10.1038/269615a0

45. Young JB, Landsberg L. Suppression of sympathetic nervous system during fasting. Science (1977) 196:1473-5. doi:10.1126/science.867049

46. Bray GA. Obesity, a disorder of nutrient partitioning: the MONA LISA hypothesis. J Nutr (1991) 121:1146-62.
47. Bray GA, York DA. The Mona Lisa hypothesis in the time of leptin. Recent Prog Horm Res (1998) 53:95-117.

Conflict of Interest Statement: The authors declare that the research was conducted in the absence of any commercial or financial relationships that could be construed as a potential conflict of interest.

Copyright (c) 2017 Barateiro, Mahú and Domingos. This is an open-access article distributed under the terms of the Creative Commons Attribution License (CC $B Y)$. The use, distribution or reproduction in other forums is permitted, provided the original author(s) or licensor are credited and that the original publication in this journal is cited, in accordance with accepted academic practice. No use, distribution or reproduction is permitted which does not comply with these terms. 